Paper to be presented at the Fifth Topical Meeting on Technology of Fusion Energy, Knoxville, Tennessee, April 26-28, 1983.

FELIX CONSTRUCTION STATUS AND EXPERIMENTAL PROGRAM* DE8.3 011749

L. R. Turner, W. F. Praeg, M. J. Knott, R. J. Lar1, D. G. McGhee and R. B. Wehrle

\author{
Electromagnetic Technology Group \\ Fusion Power Program \\ Argonne Natinnal Laboratory \\ Argonne, Ill1nois 60439
}

Submitted March 1983

DISCLAIMER

This report was prepared as an account of work sponsored by an agency of the United States Government. Neither the United States Government nor any agency thereof, nor any of their mes any warranty, express or implied, or assumes any legal liability or responsiemployees, makes any warranty, express or usefulness of any information, apparatus, product, or bility for the accuracy, completeness, or usefuld not infringe privately owned rights. Referprocess disciosed, or represents that its use would not infringe privately or service by trade name, trademark, ence herein to any specific commercial prodsarily constitute or imply its endorsement, recommanufacturer, or otherwise does not necessates Government or any agency thereor. The views mendation, or favoring by the United States Govesnessarily state or reflest these of the

and opinions of authors expressed herein do not
United States Government or any agency thereof.

*

Work supported by the U.S. Department of Energy 


\section{FELIX CONSTRUCTION STATUS AND EXPERIMENTAL PROGRAM}

L. R. Turner, W. F. Praeg, M. J. Knott, R. J. Lari, D. G. McGhee and R. B. Wehrle Argonne National Laboratory

Argonne, IL 60439

(312) 972-6257

ABSTRACT

FELIX (Fustion ELectromagnetic Induction experiment) is an experimental test facility being constructed at Argonne National Laboratory (ANL) for the study of electromagnet1c effects in the first wall/blanket/sileld (FWBS) systems of fusion reactors. The facllity design, construction status, experimental progran, instrumentation, and associated computer-code comparisons are

\section{INTRODUCTION}

The design of a fusion reactor must prevent harmful electromagnetic effects without compronlsing other needs such as described.

\begin{abstract}
neutron shlelding and remote malntenance. FELIX 18 an experimental test facility being constructed at ANL for the study of electromagnetic effects in the flrst wall/blanket/shield (FWBS) systems of fusion reactors. The FELIX progran 18 part of the FWBS Engineering Technology Program, administered by ANL. FEiIX will provide steady horizontal magnetic field of $1.0 \mathrm{~T}$ and a pulsed vertical field of $0.5 T$ over ar experimental volue of $0.76 \mathrm{~m}^{3}$. The pulsed fleld decays at rates up to $50 \mathrm{~T} / \mathrm{s}$. Several aspects of the FELIX facllity are now different from the preliminary design.l Th1s paper reports on the construction of FELIX, which will soon be complete, and the program of upcoming experiments.
\end{abstract}

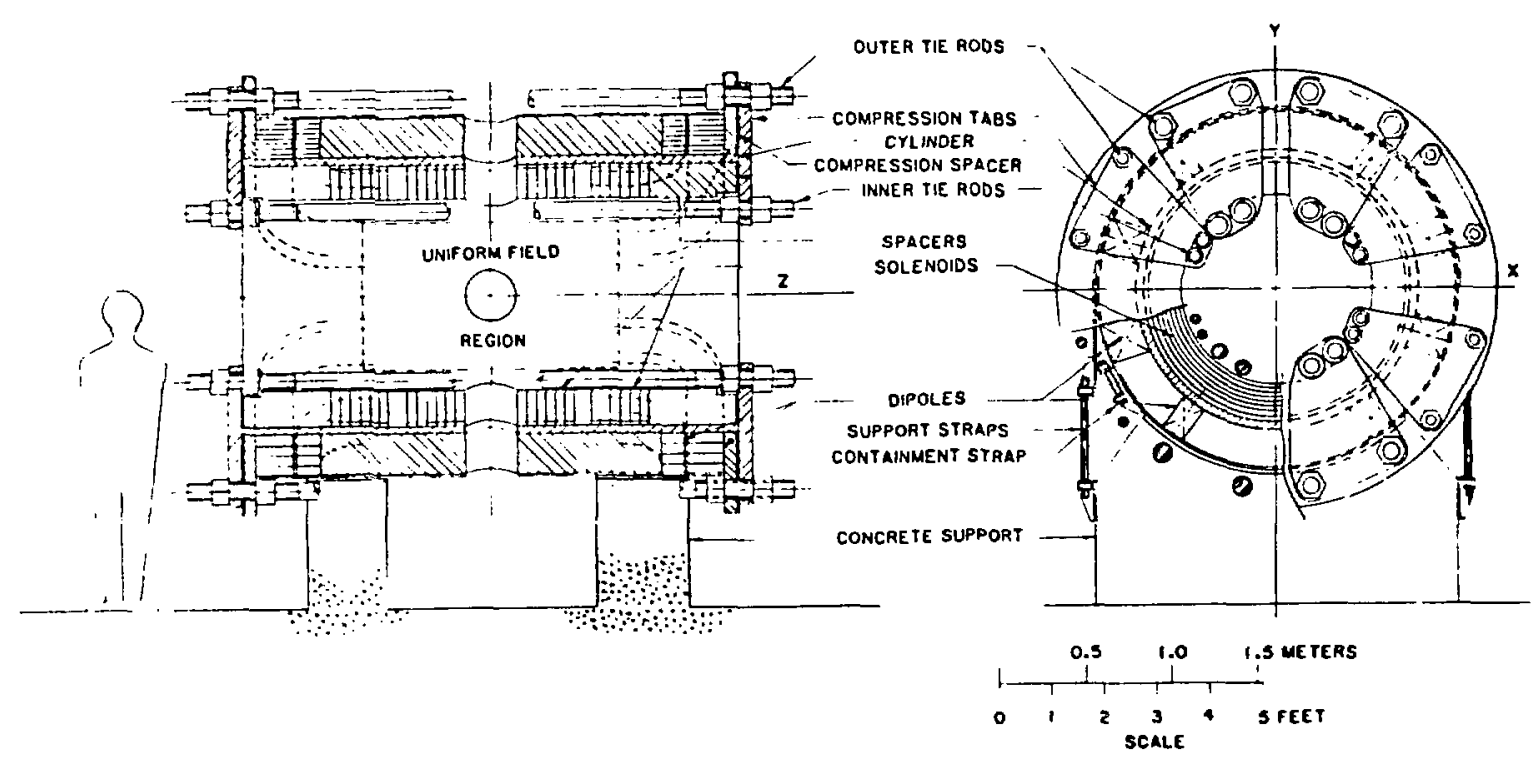

Fig. I The FELIX Facility, Showing the Solenold and ispole colls and the txperimental Volume 


\section{FACILITY DESIGN}

Figure 1 shows elevation views of FELIX. Coll reoptiolzation has reduced the slze of the colls and has reduced the energy stored in the solenold and dipole fleids by $36 z$ and $32 z$, respectively. The six large molenold colla have been replaced by 24 twolayer pancake colls. The cross section of the dipole colls has been reduced by $25 \%$. A large axlal spacing of $30.5 \mathrm{~cm}$ between the solenold pancakes at the center perolts access to the experimental volume through ports at the top. bottom, and two sides, In addition to the full-diameter access at the two ends. The ports at the two sides are used for support of the test plece, and the one at the bottom la used to cupport alrror for visual and Infrared observation of the test piece, as shown in Fig. 2.

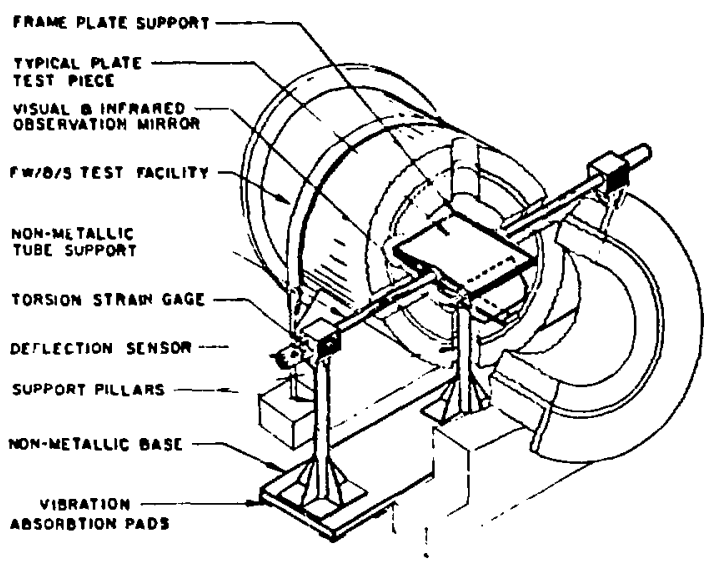

Fig. 2 Support for the Test Plece and tho $45^{\circ}$ Mirror

Thls apacing of the solenold pancakes limits the solenold field unlformity to \pm 157 over the entire $(0.9 \mathrm{~m}$ dlameter by $1.2 \mathrm{a}$ axially) experlmental volune. Over a reduced volume $(0.6$ al diameter by 1.2 m axlally) the fleld unlformity $18 \pm 5 x$.

The vertical pulsed magnetic field of 0.5 I Is prociuced by two pairs of nested dipole colls. The coll positions were chosen to approximate a $\cos \theta$ distribution of current; the fleid uniformity over the entire experimental volume is $\pm 8 \%$.
The FELIX magnets are mow mounted closer to the floor to give greater experimental access at a reduced cost. The nurber of dupport plliars has been reduced from four to two. The plllars are concrete, with footings belou floor level. Axial tle rods acrose the collo and spacera are preatressed to withotand the internal forces and moments from the coll reactions. With a central fleld of $1.0 \mathrm{~T}$ axially and $0.5 \mathrm{~T}$ vertically, the leakage fleld outside of FELIX 1 s about .080 $T$ at $2 \mathrm{~m}$, $.010 \mathrm{~T}$ at $4 \mathrm{~m}$ and $.001 \mathrm{~T}$ at $8 \mathrm{~m}$.

\section{CONSTRUCTION STATUS}

FELIX 18 echeduled for completion in July 1983. The solenold colls and dipole saddle colls are belng wound and potted and w1ll be assembled In May 1983, with testing in June 1983.

F1gure 3 shows a solenold pancake being electrically tested prlor to vacuum Impregnation with epoxy. Figure 4 is the large dipole saddle coll as 1 te rests on the mount surface of 1 ts 1mpregnation support fixture. The coll consists of four separate colls, each a two-tier pancake. The four palrs of coll leads are visible along the side of the Impregnation fixture.

All major components for the solenold and dipole wagnet power supplies have been recelved and assembled; the maln rectifier transformers, transferred to FELIX from other, completed ANL programs, are in place. Electrical connection of the transformers to the 1ncoring $13.2 \mathrm{kV}, 60 \mathrm{~Hz}$ line and to the rectifler bridges will be followed by testing Into a dummy load. Bcheduled for early May 1583. In the experimental hall, Installation of the cublcles containing switchgear, recifler bridges, fllters and the $13 \mathrm{kA}, 13$ $k V$ dipole switch is near completion. In late May, the magnets, power supplies, and raplddischarge dipole surech unit will be interconnected.

\section{EXPER IMENTAL PROGRAM}

As a typical test plece will experiere no net force and a net torque only about an axis perpendicular to both the dipols and solenold flelds, the test pleces w1ll be supported on non-metallic tubes along that ax1s. The tubes will pass through two horlzontal holes in the faclilty. Torques are measured by otrain gauges on the tube, located outside the high aagnetlc flelds. The support system is shown In Fig. 2 . 


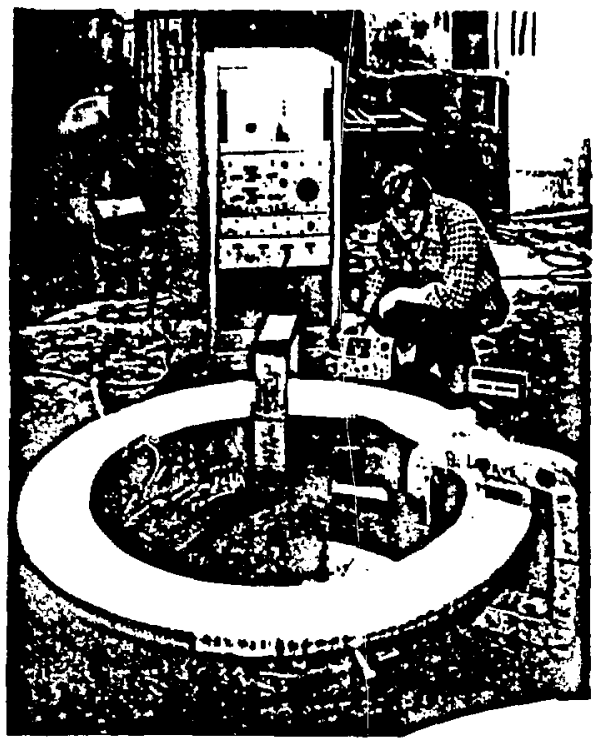

Fig. j Electrical Test of a Solenold Pancake

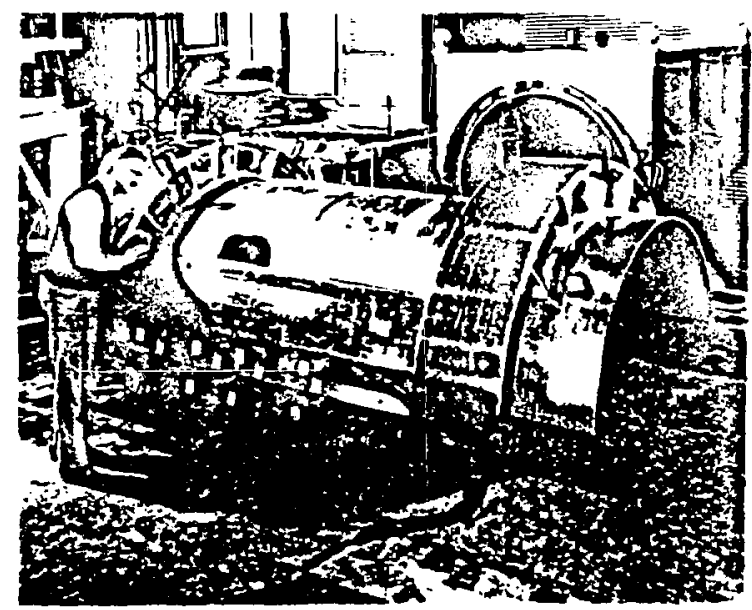

F1g. 4 Dipole Saddle Coll on the Impregnation Fixeure
Two-Dlwendonal Experlments

The flret exies of experimente to be performed when the facility is coopleted will -tudy eddy-current effects in flat plates. These two-dimensional (2D) geometrles will be the easlest to instrument and to elaulate with computer codes. Some of the objectives of the $2 D$ experinents w111 be to tudy the 20 eddycurtent pattern and the reauling flelda, forces, torques, atrases, and heating; to study the perturbing effects of sils, holes, and other geowetrical featuren; and to evaluate 20 codes. The test plece conslete of a rectangular aluminum plate $1 \mathrm{~m}$ by $0.8 \mathrm{~m}$ and 1 cor thick perpendicular to the dipole field.

The currents, flelds, temperatures, Eorces, and torques to be expected in the plate have been computed with the code EDDYNET. 2 Figure 5 shows the net force components acting on one quadrant of the plate for pulsed and steady flelds of $0.5 \mathrm{~T}$ and 1.0 T respectively. The $z$ component, which arlses from the interaction of the eddy currents with the time-independent solenold fleld, reaches 1 to peak later than the $x$ and $y$ componente, which arise from the interaction of the eddy currents with the decaying dipole field. The Insert sketches in F1g. 5 show the signs of the force components in all four quadrants of the plate. In the untform magnetic flelds, there 18 no net wagnetic force, but a net rorque peaking at $76 \mathrm{kNm}$ and 15 ms $1 \mathrm{~s}$ predicted. In carrying out the experiment, solenold fleld of $0.1 \mathrm{~T}$ will be used to make the torque wore manageable; the full solenold fleld will be needed in later experiments with smaller or segroented test pieces.

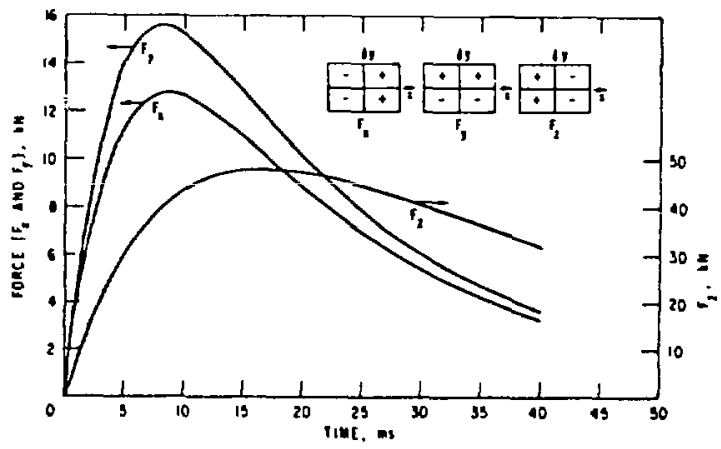

Fig. 5 Forces Acting on One Quadrant of Flat Plate Test Plece 


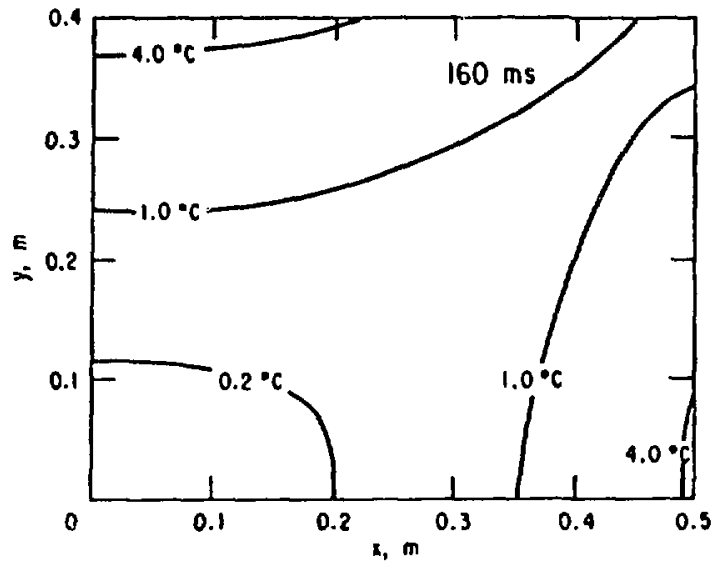

F1g. 6 Temperature Distribution Over One Quadrant of Plate

The temperature proflle over the test plece is probably the most direct means avallable of determining the overall current flow pattern in the test plece; temperature measurements w1ll be made globally with. Infrared viewing and locally with thermistors. Contour plots of temperature rise in the plate as a function of time were also calculated with EDOYNET; the plot at $160 \mathrm{~ms}$ is shown in F1g. 6. At all times the highest temperature 1s In the center of the long edge; the peak temperature is $5.1^{\circ} \mathrm{C}$ above amblent and occurs 140 ms after the start of the pulse.

In later experitients, the plate will be t1lted, 1.e., rotated about an axis (y axis) perpendiculat to both the pulsed field ( axis) and solenoid field ( $x$ axis). In such an orlentation, the plate will experience a torque about the $y$ axis even when there 18 no solenold field, with a time behavior quite different from that produced by the solenold field.

Experiments with plates containing sits and holes are Important and logical successors to those with the solid plate. Some computer codes can handle round holes more easily, others can handle square holes; both should be included in the experiments.

Among the expected output of the 2-D experiments w1ll be:
1. Experimental Information (current ind temperature distributions, corque and field perturbation as functione of time) for flat platea. Flat plates are e firatorder model of many FWBS component Begments.

2. Qualitative and, in many caes, quanticative information about che effecta of s11te and holea. Even for this elmple plate geometry. 1t may be years before the codes could provide this informetion, which is immediately applicable to estimating electromagnetic effects around penetrations of the FWBS system.

\section{Three-Dimensional Experiments}

Subsequent experiments w1ll deal with three-dimensional (3D) geometrical effects. Test pleces will include a hollow conducting cylinder and an array of conducting bricks. The eifects of segmentation and the separation between segments will be studied. Objectives of the 30 experiments include studying the eddy-current shlelding by continuous and slit hollow cylinders; studying the current patterns, heating, and forces in such cyl Inders and bricks; and evaluating 3D codes.

The aluminum alloy cylinder is $120 \mathrm{~cm}$ long, $40 \mathrm{~cm} 1 \mathrm{n}$ outside diameter, and $0.5 \mathrm{~cm}$ thick. It is supported by, but electrically insulated from, a ring at 1 ts midplane. The ring is attached to the same support structure as the plate in the previous experiment. The cylinder has two full-length slits and can be rotated so that the sllts are at any angular position. Different positions will produce different eddy current patterns.

The most 1mportant measurements are those of the fleld at different polnts along the axis. to ceterdine how the fleld penetrates the cylinder with time. The cylinder dimensions were chosen with the expectation that end effects would be small near the center of the cylinder axis.

An array of aluminum bricks will be used in the segmentation experiment. The wost Important measurements are the flelds in the spaces between bricks, as a function of time. Overall corque measurement is aso Important for cimparioon with code predictions. Complete analysis of these experiments requires a 3D computer code, and thus cannot be accomplished unt 11 a 3D code 1 . avallable; but there are immedinte results that justify dolng then early. For example, a cavity can be left in the center of a 
symetrical stack of bricks, and changes in the fleld in the cavity measured as bricks are removed or the separation between bricks is changed.

The force acting on a brick in a atack can be found by connecting all the other bricks of the stack together and then measuring the force between the atack and the remaining brick. The bricks w111 be bolted cogether, chrough Insulated holes in each brick; the Insulation separation between bricks is thereby easily varled.

Anong the expected output of the 3-D experiments will be:

1. Detalled resulta on field shielding by a cylindrical shell, with appropriate scaling rules, for use by reactor designers. Results with the shell have lmmediate applications to fleld and flux penetration through the FWBS system.

2. Detailed results on segmentation effects, with approprlate scaling rules, for use by reactor designers. The segmentation effects have lmediate Impact on the configuration of a FWBS or limfter system for any device.

3. Shlelding of a cavity in a symmetrical stack of rectangular blocks, with scaling for block slze and gap between blocks. Knowling the effect of gap size will have high Impact on blanket and shleld design because of the conflicting requirements for flux and field penetration and for avolding neutron streaming.

\section{Lacer Experiments}

Later experiments w11 Include component concepts, component models, and, finally, component prototypes. Other studies may deal with arcing, electrical contacts between FibS sectors, melt layer behavior, and growth or welding of a crack in a thin plate. As the melt layer effects are completely unknown, the first experimental aim should be to exhibit the phenomena, using any conventent molten metal. Experiments with liquid metal flow and farritic stainless steel component concepts are also under consideration.

INSTRUMENTATION AND CONTROL

Sensors to be used in the experimental program were evaluated with respect to four general requirements: they must produce the dealred signal transformation with usable accuracy and range; they hould exhiblt as much Imonity to signal interference as possible; they hould heve, the necessery dynamic characteristics; and they muet be avallable at a reasonable cost. of these requirements, nolse immunity to the expected $50 \mathrm{~T} / \mathrm{a}$ fleld changes was the moat difficult to atiofy.

\section{Strain Sensors}

The measurement of otrain is involved in three apects of the FELIX program: to monttor the structural integrity of the magnet syatem; to neasure surface strains on the test pleces: and to measure test-plece torques. The sensor chosen 18 a two layer foll strain gauge developed for use on Tokamak Fusion Test Reactor (TFTR) Btructures. It consists of two Ide:itical foll patterns superimposed and series connected so as to cancel the signal Induced by magnetic field Impulses. The lead wire connections are made to minimize their nolse contribution. Various signal wire protection techniques will be tested including special inter-twisted, two pair cable known as inter-B weave. AC excitation with $20 \mathrm{KHz}$ carrier-denodulators w111 be used to avold susceptibility to the local fields, which are $11 m i t e d$ to fequency components below $200 \mathrm{~Hz}$.

\section{Temperature Sensors}

The dependence of temperature rise on current density allows the inference of eddy current density from point measurement and full field two dimensional scanning of temperature. Point measurements will be made with low mass therwistors, the only temperature sensor which can track the temperature transients predicted by computer codes to be about $4^{\circ} \mathrm{C}$ in $40 \mathrm{~ms}$. Thermocouples will be used to callbrate the nonlinear and poorly stabllized thermistors.

Full field two-dimensional heat patterns
will be obtalned with Infrared (IR) scanning. These systems use mechanically scanned mitrors and lenses to focus a polnt of the thermal scene onto a cyrogentcally cooled sensor chosen for the expected infrared wavelength. The scene 18 reconstructed in a video format and can be digitally stored and processed by computer. The IR system chosen will provide a full acene scan in $30 \mathrm{~ms}$ or a serles of linear scans at $8 \mathrm{kHz}$ to capture transient temperature patterns. The initial flat plate objects will be viewed through the open end of FELIX along the solenold axis using front surface mirror wounted at $45^{\circ}$ under the plate, as shown In Fig. 2. 


\section{Magnetic Fleld Sensors}

Magnetic fleld mapping will be required In messuring boch the fleld patterns frow the colls alone and the disturbances to these patterns caused by eddy currents in the teat objecto. Hall probes will be used. They are exclted with $5 \mathrm{KHt}$ currents and should be able to provide transient fleld data well beyond the frequency range expected. Thelr lead wices should also be relatively immune to local electromagnetic interference. Search coll palre will also be tested for eddy current sensing and gauged sets may be used to map current densities directly.

\section{Signal Processing}

The Instrumentation and control system will Include a minicomputer, mass storage syster, and operator interaction devices. The control functions include the setting of current and timing limits for the power supplies, the timing control of the datataking system, the monttoring of various system parameters for safe operating limits, and the triggering of the shot ttrelf, including the timing of repetitive cycles. the same compter system will gather data from the various sensors, perform prelimlnary computations such as averaging, linearlzing, and conversion is more useful formats, and store the data for archival and early processing purposes.

Since it is desired to correlate data from the varlous sensors and since the number of data channels can be as h1gh as 20-30 for simple configuracions, it has been decided to digitize the data during the shot. In this way the number of channels can be increased easily and early reduction and immediate display can be programmed to occur after each shot.

The computer system will be able to store, retrleve, process, and present infrared Images using a video frame memory and a grey scale video scan converter. It will also be able to transmit data sets to ANL central computers for further processing.

\section{COMPUTER CODE COMPARISON}

Two eddy current computer codes are being installed on the IBM computers at ANL, in prepiracion of a comparison of the codes in colvitig problems relevant to FWBS concernt. NMLMAP 3 is general purpose, fintte element code for calculating magnetic fields. It treats axisymmetric or 2D geometries. In axlsymetric problems, it calculates axial and radial components of fields and toroldal eddy cutrenta in response to a specified toroldal, time-varying distribution of driving currents. TRIDIF is a finite difference code, treating the same geometry. A third, proprlecory computer code, $\mathrm{PE} 2 \mathrm{D}^{5}$ can be used for ofoflar problems. The codes will be compared on the basis of resulta, computer space and t ime requirements, and ease of use.

\section{REFERENCES}

1. H. F. PRAEG, L. R. TURNER, J. BIGGS, J. BYWATER, R. FJJA, M. KNOTT, R. J. LARI, D. G. MCGHEE, and R. B. WEHRLE, "FELIX: An Experimental Facility to Study Electromagnetic Effects for First wall. Blanket, and Shleld Systems," Proc. 9th Symposium on Englaeering Problems of Fusion Research, 1763-1766, Chlcago (1981).

2. L. R. TURNER and R. J. LARI, "Applications and Futther Developments of the Eddy Current Program EDDYNET," IEEE Transactions on Magnet1Cs, MAG-18, 416-421 (1982).

3. R. D. PILlsbURY, JR., "NMLMAP - A TwoDimensional Finite Element Program for the Transient or Static, Linear or Nonlinear Magnet1c Fleld Problem8,- IEEE Transactions on Magnet1cs, MAG-18,406-410 $(1982)$.

4. M. L. HODGDON and J. R. FREEMAN "Transient Magnetic Fleld Calculations with TRIDIF," IEEE Transactions on

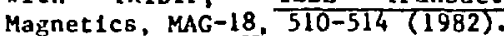

5. A. G. A. M. ARMSTRONG and C. S BIDDLECOMBE, "The PE2D Package for Transient Eddy Current Analysis," IEEE Transactions on Magnet1cs, MAG-18, $41 \overline{1-415}$ (1982). 